\title{
Polysubstituted ferrocenes as tunable redox mediators
}

\author{
Sven D. Waniek, Jan Klett ${ }^{*}$, Christoph Förster ${ }^{*}$ and Katja Heinze ${ }^{*}$
}

\author{
Full Research Paper \\ Address: \\ Institute of Inorganic Chemistry and Analytical Chemistry, Johannes \\ Gutenberg University Mainz, Duesbergweg 10-14, D-55128 Mainz, \\ Germany \\ Email: \\ Jan Klett ${ }^{*}$ - klettj@uni-mainz.de; Christoph Förster ${ }^{*}$ - \\ cfoerster@uni-mainz.de; Katja Heinze* - katja.heinze@uni-mainz.de \\ * Corresponding author \\ Keywords: \\ cyclic voltammetry; ferrocene; paramagnetic NMR spectroscopy; \\ redox mediator; spectroelectrochemistry
}

Beilstein J. Org. Chem. 2018, 14, 1004-1015.

doi:10.3762/bjoc. 14.86

Received: 09 February 2018

Accepted: 19 April 2018

Published: 07 May 2018

This article is part of the Thematic Series "Electrosynthesis II".

Guest Editor: S. R. Waldvogel

(C) 2018 Waniek et al.; licensee Beilstein-Institut.

License and terms: see end of document.

\begin{abstract}
A series of four ferrocenyl ester compounds, 1-methoxycarbonyl- (1), 1,1'-bis(methoxycarbonyl)- (2), 1,1',3tris(methoxycarbonyl)- (3) and 1,1',3,3'-tetrakis(methoxycarbonyl)ferrocene (4), has been studied with respect to their potential use as redox mediators. The impact of the number and position of ester groups present in $\mathbf{1}-\mathbf{4}$ on the electrochemical potential $E_{1 / 2}$ is correlated with the sum of Hammett constants. The $1 / \mathbf{1}^{+}-\mathbf{4} / \mathbf{4}^{+}$redox couples are chemically stable under the conditions of electrolysis as demonstrated by IR and UV-vis spectroelectrochemical methods. The energies of the $\mathrm{C}=\mathrm{O}$ stretching vibrations of the ester moieties and the energies of the UV-vis absorptions of 1-4 and $\mathbf{1}^{+}-\mathbf{4}^{+}$correlate with the number of ester groups. Paramagnetic ${ }^{1} \mathrm{H}$ NMR redox titration experiments give access to the chemical shifts of $\mathbf{1}^{+}-\mathbf{4}^{+}$and underline the fast electron self-exchange of the ferrocene/ferrocenium redox couples, required for rapid redox mediation in organic electrosynthesis.
\end{abstract}

\section{Introduction}

Since its discovery, ferrocene $(\mathrm{FcH})$ has been established as versatile redox-active building block [1-3]. Ferrocene can be reversibly oxidized to the 17 valence electron ferrocenium cation $\left(\mathrm{FcH}^{+}\right)$at a useful electrochemical potential $\left(\mathrm{FcH} / \mathrm{FcH}^{+}\right.$ $+630 \mathrm{mV}$ vs NHE; $+380 \mathrm{mV}$ vs $\mathrm{SCE}$ in $\mathrm{CH}_{3} \mathrm{CN}$ ) [4]. The $0 /+$ redox couple of ferrocene and its derivatives possesses high electron self-exchange rates $k_{\mathrm{ex}}=10^{6}-10^{7} \mathrm{M}^{-1} \mathrm{~s}^{-1}$, remarkably independent on the electrolyte and solvent $[5,6]$. Both, the ferrocene/ferrocenium and the decamethylferrocene/ decamethylferrocenium redox couples are well established as internal reference redox systems for electrochemical analyses in non-aqueous media [7-10]. Important requirements for redox couples with respect to useful applications are: (i) Both components of the redox couple should be soluble. (ii) Homogeneous and heterogeneous electron-transfer (ET) reactions should be fast. (iii) Both components should be stable under the electrolysis conditions and should not react irreversibly with any component of the supporting electrolyte [8]. In general, the redox mediators used as redox catalysts in indirect organic electrosyntheses should comprise the same characteristics [11-14]. A mediator is a reversible redox couple with a fast ET between itself and the electrode (heterogeneous) and between itself and the substrate (homogeneous). The benefit of the presence of a mediator is the switch of the sluggish heterogeneous electron 
transfer between electrode and substrate to a rapid homogeneous redox reaction between mediator and substrate. Further, the mediator's redox potential must be below or above of that of the substrate for oxidation or reduction processes, respectively. This avoids the often kinetically hindered direct ET between electrode and substrate and diminishes overoxidation or overreduction of the substrate.

Redox-active ferrocenyl derivatives find application in redox flow batteries [15], with water soluble (ferrocenylmethyl)am- monium salts acting as catholytes. Ferrocene dicarboxylic acid has been described as mediator for the voltammetric determination of glutathione in hemolized erythrocytes [16]. (Substituted) ferrocenium salts were successfully employed as single-electron transfer (SET) reagents in organic syntheses [17-28]. Tuning of the electrochemical potential of substituted ferrocenium salts promoted a selective oxidative bicyclization reaction under mild conditions (Scheme 1a) [27]. Ferrocene and decamethylferrocene act as redox catalysts in Meerwein arylation reactions [29], borylations of arenediazonium salts [30]

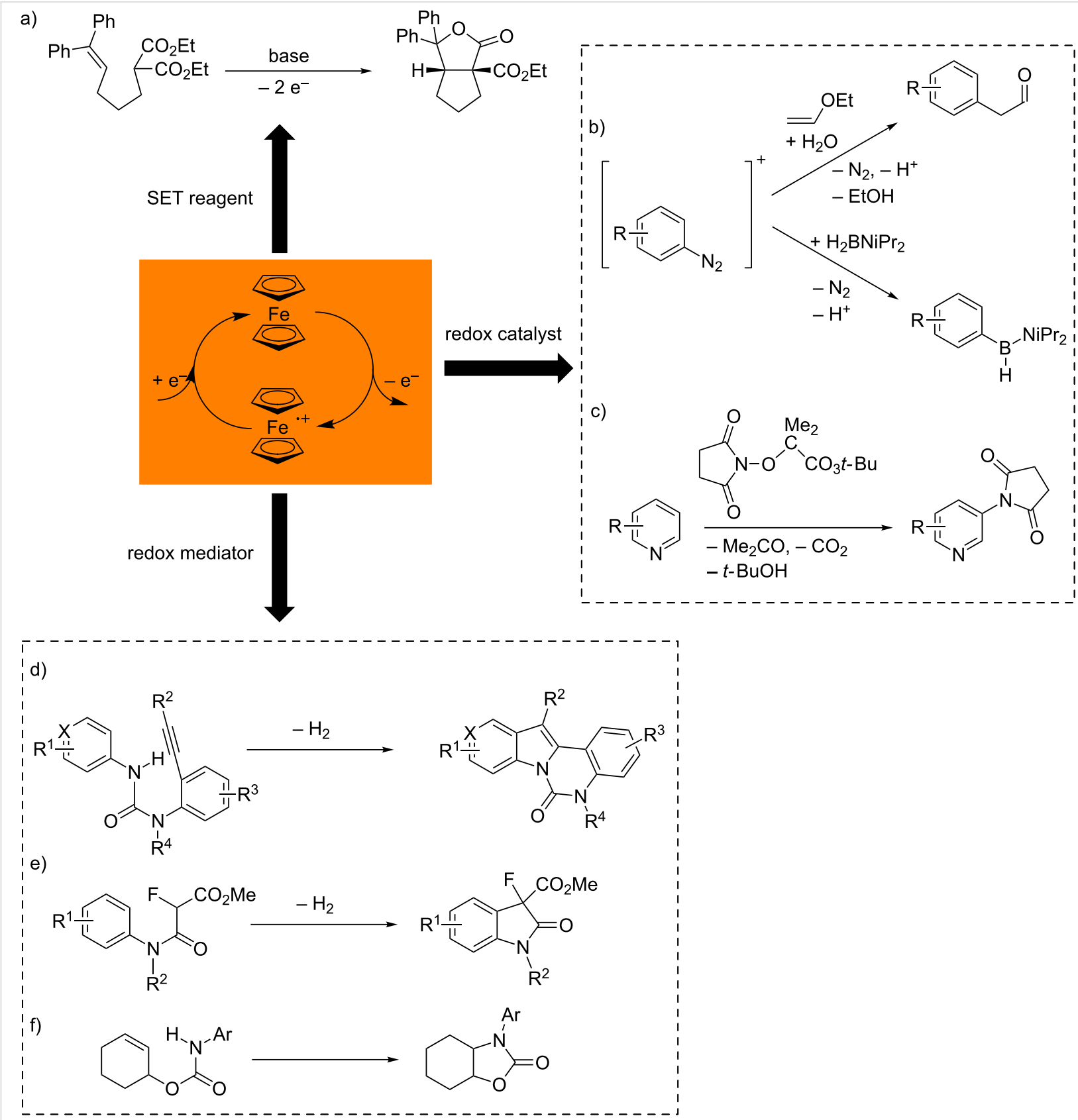

Scheme 1: Selected transformations with ferrocene/ferrocenium as SET reagents (a) [27], catalyzed (b,c) [29-31] and mediated transformations (d-f) [34-36] by the ferrocene/ferrocenium redox couple. 
and in $\mathrm{C}-\mathrm{H}$ imidation reactions of (hetero)arenes [31] (Scheme 1b,c). Ferrocene has been used as redox mediator for the electrochemical modification of carbon surfaces via electrochemical oxidation of carboxylates [32,33], as mediator for dehydrogenative coupling reactions [34,35] and for olefin hydroamidations [36] (Scheme 1d-f).

For potential applications of ferrocene derivatives as redox mediators or SET reagents, it is crucial to adjust the electrochemical potential to the potential of the substrate. The electrochemical potential of the ferrocene/ferrocenium redox couple strongly depends on the number and types of substituents [27,37-44]. One major drawback of changing the substituents is the dramatic change in chemical reactivity of ferrocene derivatives, e.g., ligand substitutions, apart from the solely intended tuning of the redox potential. A single class of ferrocene compounds with similar chemical and physical characteristics, yet covering a broad range of electrochemical potentials should circumvent this problem. To increase the ferrocene/ferrocenium potential, electron-withdrawing substituents are required. Mono-, 1,1'-diesters and a single 1,1',3-triester of ferrocene are known [45-53]. Elegant routes to 1,1',3-tris(methoxycarbonyl)ferrocene and 1,1',3,3'-tetrakis(methoxycarbonyl)ferrocene were developed only very recently [54], complementing the series of methyl esters of ferrocene carboxylic acids 1-4 (Scheme 2) [45-52].

The extremely bulky and electron-poor pentakis(methoxycarbonyl)cyclopentadienyl ligand gives a pseudo octahedral high-spin iron(II) complex $\mathbf{5}$, instead of forming a stable classical low-spin sandwich complex, precluding its application as redox mediator (Scheme 2) $[55,56]$.

Ferrocenyl esters 1-4 are synthetically accessible via the acids of $\mathbf{1}$ [45,46], 2 [57], $\mathbf{3}$ and $\mathbf{4}$ [54] in a direct selective metalation of ferrocene [54,57-60], quenching with carbon dioxide, followed by esterification [45-48,54]. The 1,1'-disubstituted ferrocene 2 can also be obtained by direct coordination of the respective substituted cyclopentadienyl ligand (CpR) to iron(II) [49]. An alternative route to the mono-, 1,1'-di- and 1,1',3-tricarboxylic acids of ferrocene is the oxidation of the respective acetylferrocenes $[47,48,53]$. Ferrocene carboxylic acid is also available via basic hydrolysis of ferrocenyl aryl ketones [61]. Together with the redox potentials of ferrocene, $\mathbf{1}$ and $\mathbf{2}$, the hitherto unknown electrochemical potentials of $\mathbf{3}$ and $\mathbf{4}$ should cover a wide potential range. This will meet the requirements of different substrates for the potential application of 1-4 and their ferrocenium ions as selective redox mediators or SET reagents. Apart from the redox potentials of the redox mediators $\mathrm{FcH}$ and $\mathbf{1 - 4}$, the stability of the 18 and 17 valence electron species as well as their solubility and the availability of spectroscopic probes to monitor reaction progress and stability are important issues. These fundamental aspects will be addressed in this study.

Herein, a detailed study of the properties of $\mathbf{1 - 4}$ and their ferrocenium ions $\mathbf{1}^{+}-\mathbf{4}^{+}$in solution is reported including electrochemical methods (cyclic voltammetry and square wave voltammetry; CV, SWV) and covering investigations regarding the stability of $\mathbf{1}-\mathbf{4} / \mathbf{1}^{+}-\mathbf{4}^{+}$by spectroelectrochemical methods (UV-vis, IR) [62-68]. In addition, the mediators $\mathbf{1} / \mathbf{1}^{+}-\mathbf{4} / \mathbf{4}^{+}$are probed by paramagnetic NMR spectroscopic methods [69-73]. The results are supported with (time-dependent) density functional theoretical (TD)-DFT methods.

\section{Results and Discussion Electrochemistry of esters 1-4}

The esters 1-4 were studied by cyclic and square wave voltammetry in $0.1 \mathrm{M} \mathrm{CH}_{2} \mathrm{Cl}_{2}$ solutions of $\left[n-\mathrm{Bu}_{4} \mathrm{~N}\right]\left[\mathrm{B}\left(\mathrm{C}_{6} \mathrm{~F}_{5}\right)_{4}\right]$, using platinum working and counter electrodes. All esters $\mathbf{1}-\mathbf{4}$ show

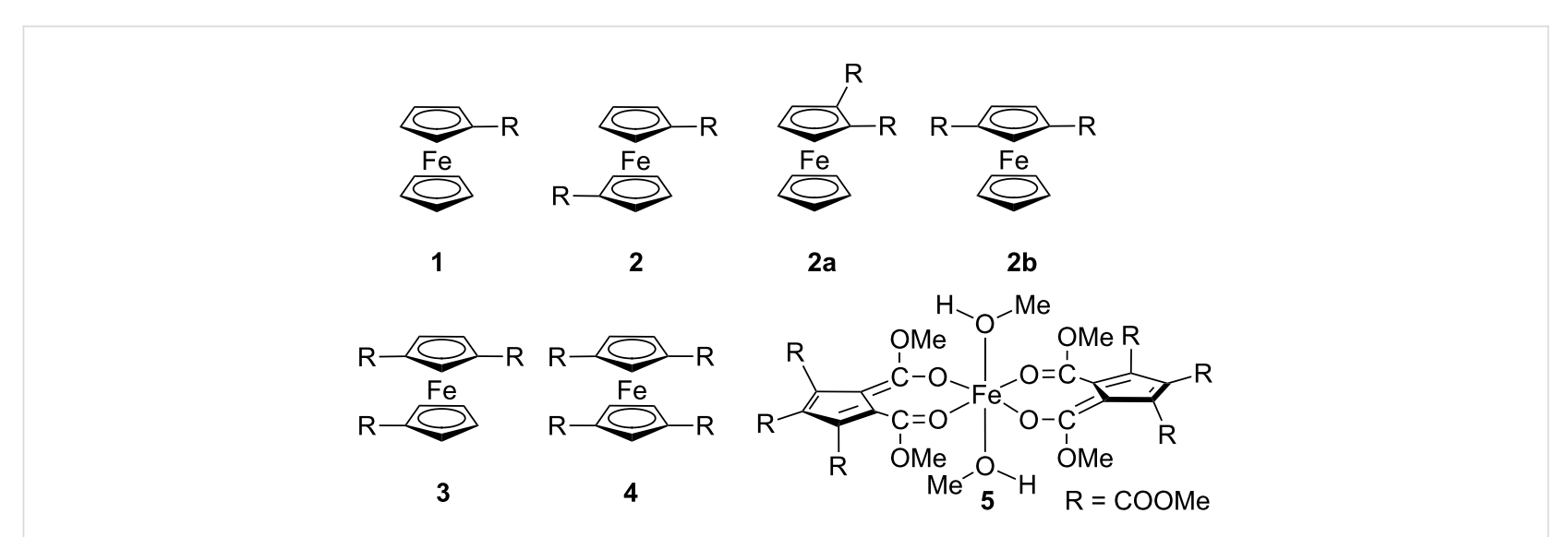

Scheme 2: Methyl esters of ferrocene carboxylic acids 1 [45,46], 2 [47-49], 2a [50], 2b [51,52], 3, 4 [54] and pseudo octahedral high-spin iron(II) complex $\mathbf{5}$ with pentakis(methoxycarbonyl)cyclopentadienyl ligands $[55,56]$. 
an essentially reversible behaviour for the ferrocene/ferrocenium oxidation process (Figure 1, Figure S1, Supporting Information File 1). The electrochemical potentials cover a wide range, $E_{1 / 2}=260-900 \mathrm{mV}$ vs $\mathrm{FcH} / \mathrm{FcH}^{+}$(Figure 1, Table 1).

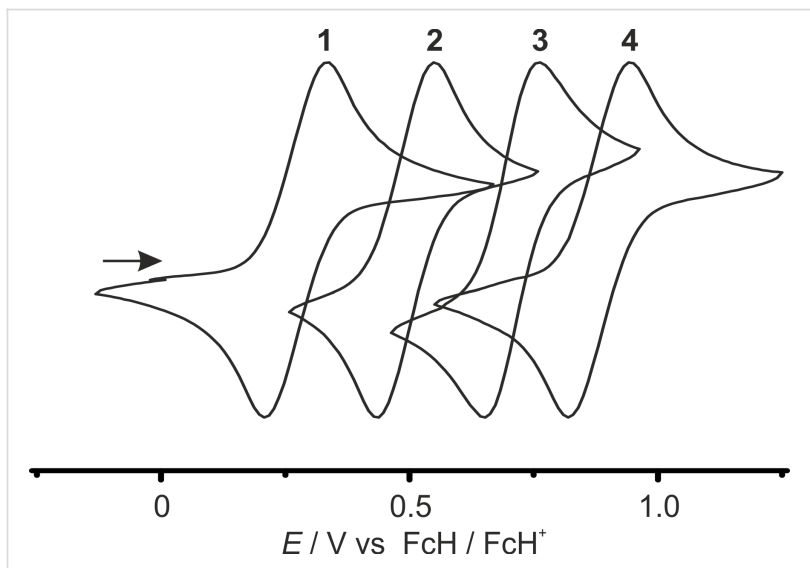

Figure 1: Normalized cyclic voltammograms for anodic sweeps of 1-4 in $\mathrm{CH}_{2} \mathrm{Cl}_{2} /\left[n-\mathrm{Bu}_{4} \mathrm{~N}\right]\left[\mathrm{B}\left(\mathrm{C}_{6} \mathrm{~F}_{5}\right)_{4}\right]$ (scan rate $100 \mathrm{mV} \mathrm{s}^{-1}$ ).

Table 1: Electrochemical data of esters 1-4 and sum of Hammett substituent constants $\sigma_{\mathrm{p}}{ }^{\mathrm{a}}$ and $\sigma_{\mathrm{m}}{ }^{\mathrm{a}}$.

\begin{tabular}{llll} 
& $E_{1 / 2}[\mathrm{mV}]^{b}$ & $\sum \sigma_{\mathrm{p} / \mathrm{m}}$ & $\sum \sigma_{\mathrm{p}}$ \\
\hline $\mathbf{1}$ & 260 & $\sigma_{\mathrm{p}}=0.45$ & 0.45 \\
$\mathbf{2}$ & 495 & $2 \sigma_{\mathrm{p}}=0.90$ & 0.90 \\
$\mathbf{3}$ & 700 & $2 \sigma_{\mathrm{p}}+\sigma_{\mathrm{m}}=1.27$ & 1.35 \\
$\mathbf{4}$ & 900 & $2 \sigma_{\mathrm{p}}+2 \sigma_{\mathrm{m}}=1.64$ & 1.80 \\
\hline
\end{tabular}

${ }^{a} \sigma_{p}=0.45, \sigma_{m}=0.37$ for COOMe substituent [74]. ${ }^{b} v_{s s} \mathrm{FcH} / \mathrm{FcH}^{+}$.

The oxidation potential of the tetraester 4 is very high with $E_{1 / 2}=900 \mathrm{mV}$. To the best of our knowledge, higher oxidation potentials (vs $\mathrm{FcH} / \mathrm{FcH}^{+}$) have been observed only for $1,1^{\prime}, 2,2^{\prime}, 4,4^{\prime}$-hexakis(pentafluorophenyl)ferrocene (940 $\mathrm{mV}$ in $\mathrm{CH}_{2} \mathrm{Cl}_{2}$ ) [40], 1,1',2,2',3,3'-hexakis(pentafluorophenyl)ferrocene $\left(951 \mathrm{mV}\right.$ in $\mathrm{CH}_{2} \mathrm{Cl}_{2}$ ) [40], decachloroferrocene $\left(E_{\mathrm{p}}=1246 \mathrm{mV}\right.$ in $\mathrm{MeCN}$ ) [37], 1,1',2-tri(formyl)ferrocene (910 $\mathrm{mV}$ in $\mathrm{CH}_{2} \mathrm{Cl}_{2}$ at $-40{ }^{\circ} \mathrm{C}$ ) [38] and $1,1{ }^{\prime}, 2,2^{\prime}$ tetra(formyl)ferrocene $\left(1145 \mathrm{mV}\right.$ in $\mathrm{CH}_{2} \mathrm{Cl}_{2}$ at $\left.-40{ }^{\circ} \mathrm{C}\right)$ [38] The latter three are only irreversibly oxidized at room temperature precluding any application as mediators. The data are in full accordance with the increasing electron-withdrawing character of the cyclopentadienyl ligands from 1 to 4 . The position of the ester groups has a slight influence on the electrochemical potential. 1- or 1'-substitution with a methoxycarbonyl group raises the potential by ca. $250 \mathrm{mV}(\mathrm{FcH} \rightarrow \mathbf{1}, \mathbf{1} \rightarrow \mathbf{2})$, while substitution in 3- and 3'-position has only a smaller impact with an increase of the potential by ca. $200 \mathrm{mV}(\mathbf{2} \rightarrow \mathbf{3}, \mathbf{3} \rightarrow \mathbf{4})$. According to Lever et al. [39], the calculated electrochemical pa- rameters $E_{\mathrm{L}}(\mathrm{L})$ for 1-(methoxycarbonyl)cyclopentadienyl and 1,3-bis(methoxycarbonyl)cyclopentadienyl ligands amount to $E_{\mathrm{L}}\left(\mathrm{L}_{1}\right)=250 \mathrm{mV}$ and $E_{\mathrm{L}}\left(\mathrm{L}_{2}\right)=450 \mathrm{mV}$ vs $\mathrm{FcH} / \mathrm{FcH}^{+}$, respectively. Indeed, the electrochemical potential $E_{1 / 2}=700 \mathrm{mV}$ of 3 perfectly corresponds to the sum $E_{\mathrm{L}}\left(\mathrm{L}_{1}\right)+E_{\mathrm{L}}\left(\mathrm{L}_{2}\right)=700 \mathrm{mV}$. Consequently, the ligand contributions to the electrochemical potential of substituted cyclopentadienyl complexes are essentially additive for $\mathbf{1}-\mathbf{4}$.

This characteristic relationship is supported by correlating the electrochemical data with the Hammett substituent constants [37,39,74,75]. Typically, the $E_{1 / 2}$ data of substituted ferrocenes correlate linearly with the sum $\sum \sigma_{p}$ of the Hammett values $\sigma_{p}$ of para-substituents [37,39,74].

For esters 1-4, the electrochemical potentials $E_{1 / 2}$ (vs FcH/ $\mathrm{FcH}^{+}$) versus sum of Hammett values $\sum \sigma_{\mathrm{p}}$ did not give a satisfactory linear relation. Within this approach, the relative positions of ester groups and hence their different electronic influence to the electrochemical potential is not considered. The influence of a methoxycarbonyl substituent in 1- or 1'-position is indeed best described with $\sigma_{\mathrm{p}}=0.45$ [75]. On the other hand, substituents in the 3- or 3'-position require using $\sigma_{\mathrm{m}}=0.37$ [75] for meta-substituents, to give an excellent linear correlation of $E_{1 / 2}$ with $\sum \sigma_{\mathrm{p} / \mathrm{m}}$ (Figure 2, Table 1).

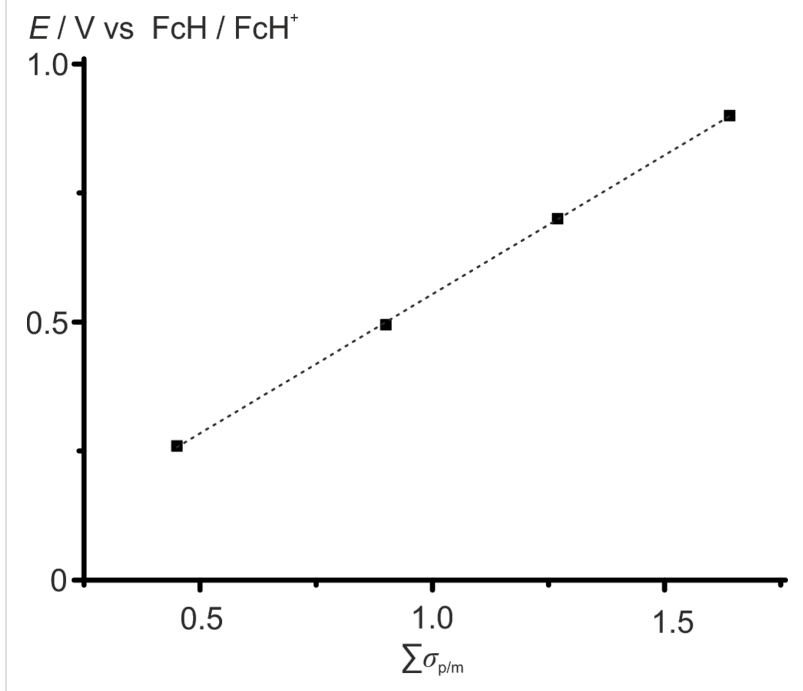

Figure 2: Electrochemical potentials $E_{1 / 2}\left(\right.$ vs $\left.\mathrm{FcH} / \mathrm{FcH}^{+}\right)$of esters 1-4 versus sum of Hammett values $\sum \sigma_{\mathrm{p} / \mathrm{m}}$ with linear regression $\left(E_{1 / 2}=0.539 \mathrm{~V} \cdot \sum \sigma_{\mathrm{p} / \mathrm{m}}+0.015 \mathrm{~V}, R^{2}=0.9999\right)$.

The generalizable use of $\sigma_{\mathrm{p}}$ and especially $\sigma_{\mathrm{m}}$ to include the effect on the relative positions of substituents for $E_{1 / 2}$ of polysubstituted ferrocenes has to be further validated with other series of polysubstituted ferrocenes. 


\section{IR spectroelectrochemistry of esters 1-4}

In the attenuated total reflection (ATR) IR spectra of solid samples of esters 1-4, several overlapping bands for the $\mathrm{C}=\mathrm{O}$ stretching vibrations of the ester substituents are observed between 1678 and $1730 \mathrm{~cm}^{-1}$ (Figure 3a, Figures S2-S6, Table S1, Supporting Information File 1). DFT calculations (B3LYP, def2-TZVP, RIJCOSX, ZORA, CPCM $\left.\left(\mathrm{CH}_{2} \mathrm{Cl}_{2}\right)\right)$ on di-, triand tetraesters 2-4 suggest an intramolecular coupling of the $\mathrm{C}=\mathrm{O}$ vibrations of the ester moieties substantiating the number of observed bands (Table S1, Supporting Information File 1). Furthermore, crystal packing effects with intermolecular $\mathrm{C}=\mathrm{O} \cdots \mathrm{H}-\mathrm{C}$ interactions, differing in strengths, can be responsible for the occurrence of distinguishable $\mathrm{C}=\mathrm{O}$ bands $[54,76,77]$. For example, two different molecules of monoester $\mathbf{1}$ are present in the asymmetric unit of the solid-state structure [76], leading to different $\mathrm{C}=\mathrm{O}$ stretching vibration bands (Figure $3 \mathrm{a}$ ).

In contrast to the solid-state IR spectra, only a single broad $\mathrm{C}=\mathrm{O}$ band is observed for 1-4 in solution (Figure 3, Figure 4, Figures S7-S14, Supporting Information File 1). In the series 1-4, the $\mathrm{C}=\mathrm{O}$ bands shift to higher wavenumbers in solution $\tilde{v}_{\mathrm{CO}}=1712-1724 \mathrm{~cm}^{-1}$ with increasing number of electronwithdrawing COOMe groups (Figure 3b). The DFT calculated IR spectra with unscaled energies of the $\mathrm{C}=\mathrm{O}$ vibrations $\tilde{v}_{\max (\mathrm{CO})}=1710-1724 \mathrm{~cm}^{-1}$ fully support these findings (Table S1, Figures S15-S22, Supporting Information File 1).

a)

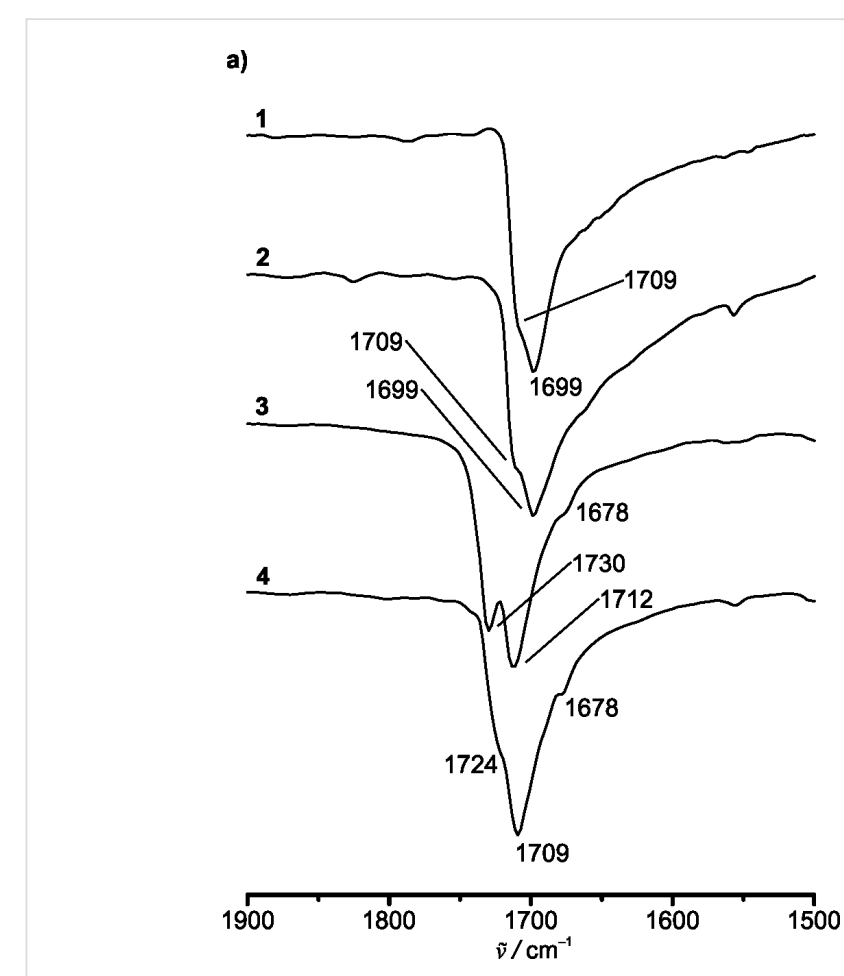

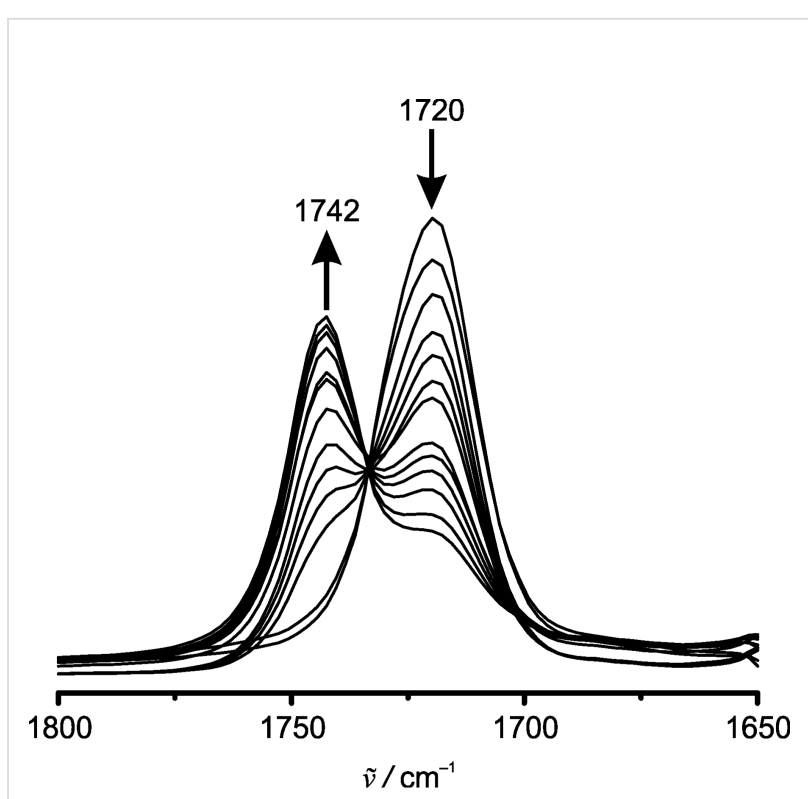

Figure 4: IR spectroelectrochemical oxidation of $\mathbf{3}$ to $\mathbf{3}^{\mathbf{+}}$ in $\mathrm{CH}_{2} \mathrm{Cl}_{2} /\left[n-\mathrm{Bu}_{4} \mathrm{~N}\right]\left[\mathrm{B}\left(\mathrm{C}_{6} \mathrm{~F}_{5}\right)_{4}\right](\mathrm{C}=\mathrm{O}$ stretching vibration region, 0.4-1.1 $\mathrm{V}$ vs $\mathrm{Ag}$ pseudo reference electrode).

Compounds 1-4 can be reversibly oxidized to $\mathbf{1}^{+}-\mathbf{4}^{+}$in dichloromethane and $\left[n-\mathrm{Bu}_{4} \mathrm{~N}\right]\left[\mathrm{B}\left(\mathrm{C}_{6} \mathrm{~F}_{5}\right)_{4}\right]$ as supporting electrolyte in an IR spectroelectrochemical (SEC) cell, confirming

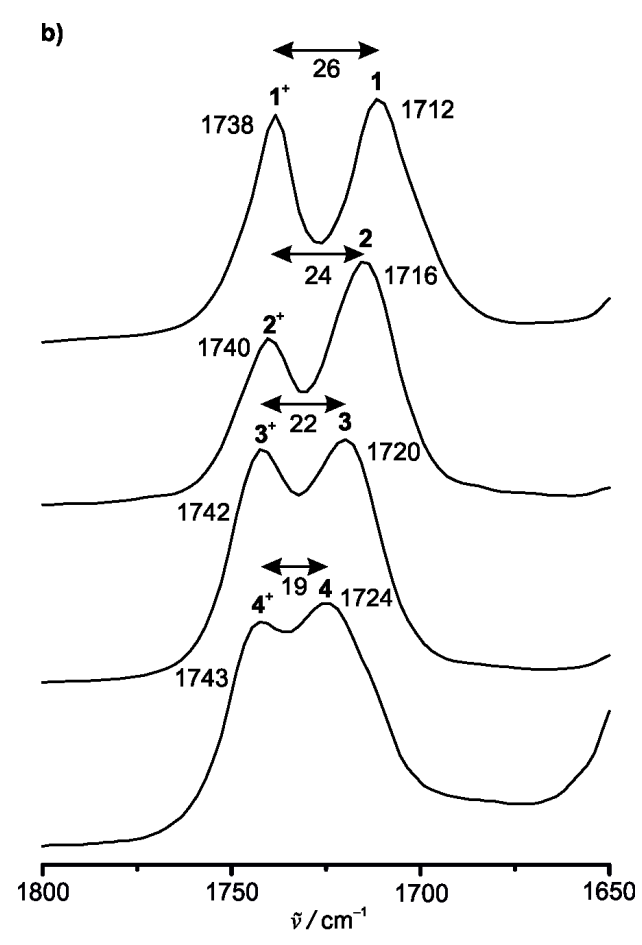

Figure 3: a) Partial ATR IR spectra (transmission normalized, $C=O$ stretching vibration region) of solids 1-4. b) Partial spectroelectrochemical IR

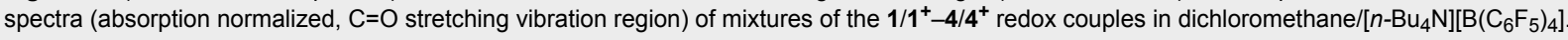


the chemical stability of the ferrocenyl esters under the conditions of electrolysis (Figure 3b, Figure 4, Figures S7-S14, Table S1, Supporting Information File 1).

Triester 3 and tetraester $\mathbf{4}$ cannot be quantitatively oxidized to $3^{+}$and $\mathbf{4}^{+}$in the SEC cell up to a potential of $1.1 \mathrm{~V}$ and $1.4 \mathrm{~V}$ respectively, probably due to a fast diffusion of $\mathbf{3}$ and $\mathbf{4}$ to the anode in the beam path (Figure 4, Figures S11-S14, Supporting Information File 1). In addition, precipitation of some poorly soluble $[\mathbf{4}][\mathbf{X}]$ also occurs. During oxidation to the respective ferrocenium cations, the $\mathrm{C}=\mathrm{O}$ stretching vibration bands of 1-4 decrease in intensity, while the $\mathrm{C}=\mathrm{O}$ bands of $\mathbf{1}^{+}-\mathbf{4}^{+}$appear, crossing in clean isosbestic points. Expectedly, the $\mathrm{C}=\mathrm{O}$ stretching vibrations of $\mathbf{1}^{+}-\mathbf{4}^{+}$are shifted to higher wavenumbers by $26-19 \mathrm{~cm}^{-1}\left(\tilde{\mathrm{v}}_{\mathrm{CO}}=1738-1743 \mathrm{~cm}^{-1}\right)$ with an increasing electron-withdrawing character of the Cp ligands. The substituent effect is attenuated by the positive charge at the iron atom in $\mathbf{1}^{+}-\mathbf{4}^{+}\left(\Delta \tilde{\mathrm{v}}_{\mathrm{CO}}=5 \mathrm{~cm}^{-1}\right)$, compared to $\mathbf{1}-\mathbf{4}$ $\left(\Delta \tilde{v}_{\mathrm{CO}}=12 \mathrm{~cm}^{-1}\right)$, respectively (Figure $3 \mathrm{~b}$, Table S1, Figures S7-S14, Supporting Information File 1) [78]. The unscaled energies of the DFT calculated $\mathrm{C}=\mathrm{O}$ bands of $\mathbf{1}^{+}-\mathbf{3}^{+}$fit very well to the experimental observations of $\mathbf{1}^{+}-\mathbf{3}^{+}$(Figures S7-S12, S16, S18, S20, Table S1, Supporting Information File 1). Unexpectedly, the calculated $\tilde{v}_{\mathrm{CO}}$ data of $\mathbf{4}^{+}$are significantly lower than the experimental ones, which remain unexplained at the moment.

For all redox couples of the ferrocenyl esters, the $\mathrm{C}=\mathrm{O}$ stretching vibration delivers a useful in operando probe substantiating the stability of the redox mediator and enabling quantification of both redox partners and hence estimation of the actual concentration-dependent redox potential in solution.

\section{UV-vis spectroelectrochemistry of esters 1-4}

Analogous to the IR-SEC experiments, the esters 1-4 were also probed by UV-vis-SEC investigations. The UV-vis spectra of 1-4 recorded in dichloromethane show the ferrocene ligand field absorption band at $\lambda_{\max }=444,449,455$ and $457 \mathrm{~nm}$, which is typically around $\lambda_{\max } \approx 440-490 \mathrm{~nm}[66,70,79,80]$ (Figure 5a). a)
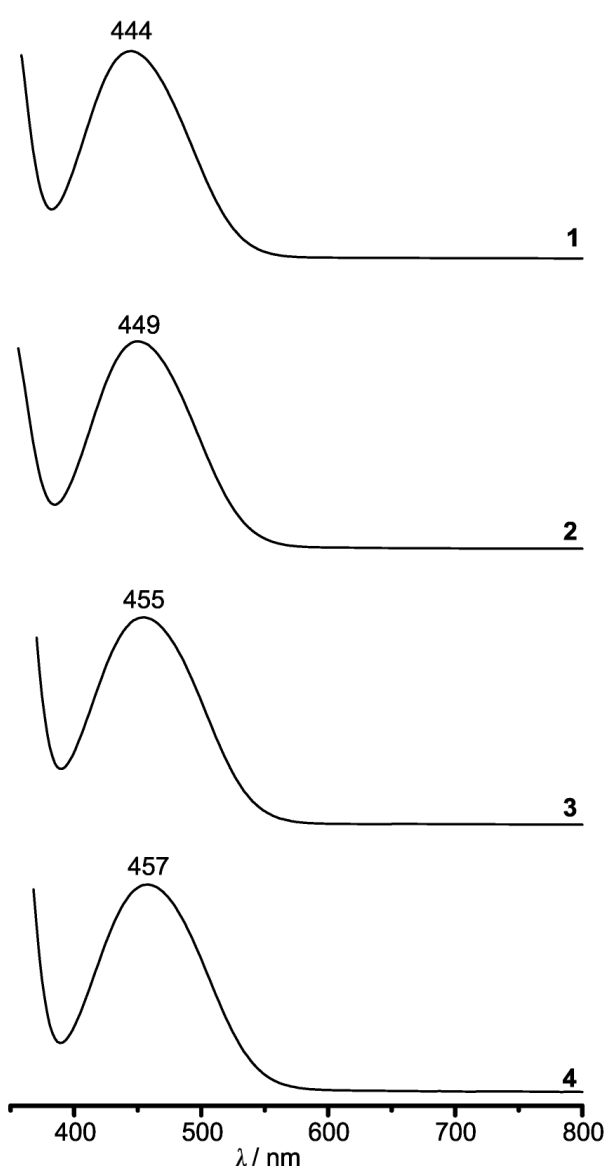

b)
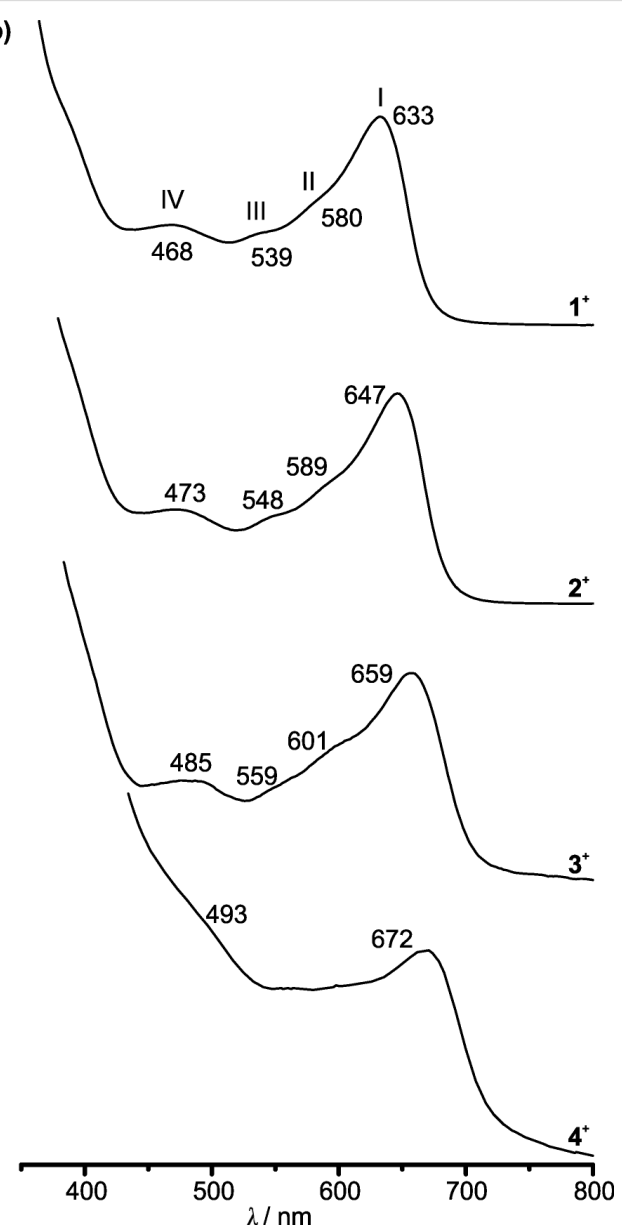

Figure 5: a) Normalized UV-vis spectra of 1-4 in $\mathrm{CH}_{2} \mathrm{Cl}_{2}$. b) Normalized UV-vis absorptions of $\mathbf{1}^{+}-\mathbf{4}^{+}$in $\mathrm{CH}_{2} \mathrm{Cl}_{2} /\left[n-\mathrm{Bu}_{4} \mathrm{~N}\right]\left[\mathrm{B}\left(\mathrm{C}_{6} \mathrm{~F}_{5}\right) 4\right]$ after spectroelectrochemical oxidation of 1-4. 
The energy of the absorption bands decreases almost linearly with the number $n$ of the electron-withdrawing COOMe substituents for 1-4 (Figure 6a).

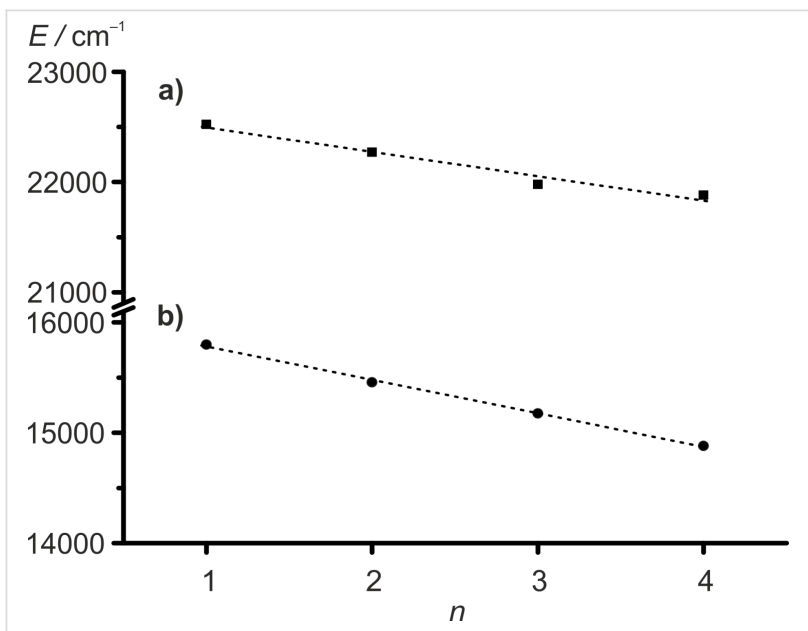

Figure 6: Absorption energy $E$ of ferrocene bands of 1-4 (a) and energies of the low energy absorption maxima at around $\lambda_{\max } \approx 630-670 \mathrm{~nm}$ of $1^{+}-4^{+}$(b) versus number of methoxycarbonyl substituents $n$ with regression lines

a) $E=-222 \mathrm{~cm}^{-1} \cdot n+22700 \mathrm{~cm}^{-1}, R^{2}=0.9824$;

b) $E=-303 \mathrm{~cm}^{-1} \cdot n+16100 \mathrm{~cm}^{-1}, R^{2}=0.9991$.

The reversible oxidation of 1-4 in UV-vis-SEC experiments in $\mathrm{CH}_{2} \mathrm{Cl}_{2} /\left[n-\mathrm{Bu}_{4} \mathrm{~N}\right]\left[\mathrm{B}\left(\mathrm{C}_{6} \mathrm{~F}_{5}\right)_{4}\right]$ is monitored by the decreasing band intensity of the ferrocene absorption and the appearance of a set of four partially resolved characteristic ferrocenium absorptions (bands I-IV) responsible for the blue color (Figure 5b and Figure 7, Figures S23-S31, Supporting Information File 1).

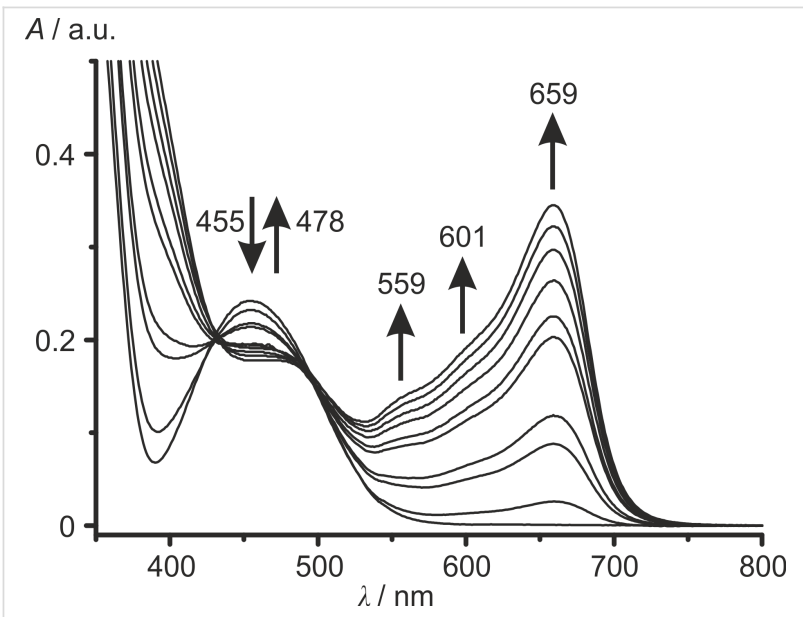

Figure 7: UV-vis spectroelectrochemical oxidation of 3 in $\mathrm{CH}_{2} \mathrm{Cl}_{2}$ / $\left[n-\mathrm{Bu}_{4} \mathrm{~N}\right]\left[\mathrm{B}\left(\mathrm{C}_{6} \mathrm{~F}_{5}\right)_{4}\right](0-1.1 \mathrm{~V}$ vs $\mathrm{Ag}$ pseudo reference electrode).

Isosbestic points indicate clean conversions of $\mathbf{1} \rightarrow \mathbf{1}^{+}, \mathbf{2} \rightarrow \mathbf{2}^{+}$ and $\mathbf{3} \rightarrow \mathbf{3}^{+}$, respectively. For example, this set of bands and shoulders (sh) IV-I is observed at $\lambda_{\max }=485 \mathrm{~nm}$ (IV), $\lambda_{\mathrm{sh}}=559 \mathrm{~nm}$ (III), $601 \mathrm{~nm}$ (II) and $\lambda_{\max }=659 \mathrm{~nm}$ (I) for $3^{+}$. During oxidation of 4 to $\mathbf{4}^{+}$, isosbestic points between the absorption bands of $\mathbf{4}$ and $\mathbf{4}^{+}$cannot be observed (Figures S29 and S30, Supporting Information File 1). Probably, precipitation of the poorly soluble tetraester $4^{+}$could be responsible for this effect, as already suggested for the IR-SEC experiments of $\mathbf{4} / \mathbf{4}^{+}$. On the other hand, isosbestic points are observed in the UV-vis spectra upon re-reduction of $4^{+}$to 4 (Figure S31, Supporting Information File 1). The energy of the absorptions of the ferrocenium cations $\mathbf{1}^{+}-\mathbf{4}^{+}$decreases with the electron-withdrawing nature of the $\mathrm{Cp}$ ligands in the series $\mathbf{1}^{+}-\mathbf{4}^{+}$, similar to the vis absorption maxima of the neutral ferrocenes $\mathbf{1}-\mathbf{4}$. For the prominent band I of the cations $\mathbf{1}^{+}-\mathbf{4}^{+}$, a linear and stronger dependency of the energy on the number $n$ of methoxycarbonyl substituents can be found than for the ligand field band of the ferrocenes 1-4 (Figure 6b). The lowest energy band (band I) in the UV-vis spectra of $\mathbf{1}^{+}-\mathbf{4}^{+}$is assigned to ligand-to-metal charge transfer (LMCT) transitions [79,81-83]. The bands II-IV are assigned to mainly $\mathrm{d}-\mathrm{d}$ transitions [79]. TD-DFT calculations on the B3LYP, def2-TZVP, RIJCOSX, ZORA, CPCM $\left(\mathrm{CH}_{2} \mathrm{Cl}_{2}\right)$ level do not give satisfactory results concerning energy, number of bands and oscillator strength of electronic transitions (Figures S32-S35, Supporting Information File 1). The poor agreement of TD-DFT calculated electronic spectra of metallocenes and derivatives with experimental data has been noted before. Improvements have been achieved by testing different functionals [84,85] and by including vibrational distortions of the ferrocene geometry into the calculations [86]. Nevertheless, the LMCT character of the prominent band I is confirmed by the calculations. The intensity of band I scales with the amount of the corresponding ferrocenium ion present and consequently the actual potential in solution can be estimated by UV-vis spectroscopy.

\section{NMR spectroscopy of esters $1-4$ and $\mathbf{1}^{+}-\mathbf{4}^{+}$}

In contrast to typical organic paramagnetic redox mediators, the relaxation properties of proton nuclei of paramagnetic ferrocenium derivatives allow the observation of reasonable sharp resonances [87]. The fast electron self-exchange of the ferrocene/ ferrocenium redox couple and derivatives on the NMR timescale leads to the observation of resonances with averaged chemical shifts $\delta$ in the ${ }^{1} \mathrm{H}$ NMR spectra of ferrocene/ferrocenium mixtures $[5,6,70-72]$. The molar fraction of $\mathrm{FcH} / \mathrm{FcH}^{+}$can be calculated from the averaged ${ }^{1} \mathrm{H}$ NMR resonance frequencies of a mixture and the known resonance frequencies of $\mathrm{FcH}$ and $\mathrm{FcH}^{+}$, respectively [6]. This relation gives $\chi_{\mathrm{P}}=\left(\delta-\delta_{\mathrm{D}}\right) /\left(\delta_{\mathrm{P}}-\delta_{\mathrm{D}}\right)$ for the molar fraction of the paramagnetic species, expressed in the chemical shift scale with $\delta_{\mathrm{D}}$ being the chemical shift of the diamagnetic species, $\delta_{\mathrm{P}}$ being the 
resonance of the paramagnetic species and $\delta$ being the averaged chemical shift of the mixture.

The detection of the resonances of $\mathbf{1} / \mathbf{1}^{+}-\mathbf{4} / \mathbf{4}^{+}$should allow for determining the ratio of $1: 1^{+}-4: 4^{+}$by in situ NMR experiments. Thus, titration of 1-4 with Magic Green, tris(2,4-dibromophenyl)ammoniumyl hexachloroantimonate [10], as a strong oxidant $\left(E_{1 / 2}=1140 \mathrm{mV}\right.$ in $\mathrm{MeCN}$ vs $\left.\mathrm{FcH} / \mathrm{FcH}^{+}\right)$in $\mathrm{CD}_{2} \mathrm{Cl}_{2}$ under NMR monitoring shows that the $\mathrm{Cp}$ proton resonances broaden upon oxidation and shift to lower field, while the methyl proton resonances of the ester substituents shift to higher field and remain much sharper (Figure 8, Table 2, Figures S36-S38, Supporting Information File 1).

In some cases, e.g., $\mathbf{3}^{+}$, the different $\mathrm{Cp}$ protons can still be distinguished in spite of the broadened resonances (Figure 8). The broadening is much more severe for the $\mathrm{Cp}$ proton resonances, while the methyl proton resonances are still rather sharp allowing the discrimination and assignment of the different methyl protons of $\mathbf{3}^{+}$(Figure 8 ).

With an increasing number of ester groups, the proton resonances of the mono- and disubstituted $\mathrm{Cp}$ ligands and of the methyl groups shift to lower field for 1-4 (CpR: $1 \rightarrow \mathbf{2} \rightarrow \mathbf{3}$, $\mathrm{CpR}_{2}: \mathbf{3} \rightarrow \mathbf{4}$ ), while for $\mathbf{1}^{+}-\mathbf{4}^{+}$, the $\mathrm{Cp}$ ligand proton resonances shift to lower field and the methyl proton resonances shift to higher field ( $\mathrm{CpR}: \mathbf{1}^{+} \rightarrow \mathbf{2}^{+} \rightarrow \mathbf{3}^{+}, \mathrm{CpR}_{2}: \mathbf{3}^{+} \rightarrow \mathbf{4}^{+}$).
This substituent effect is larger for the paramagnetically shifted resonances of $\mathbf{1}^{+}-\mathbf{4}^{+}$than for the diamagnetic complexes $\mathbf{1}-\mathbf{4}$.

In $\mathrm{CD}_{3} \mathrm{CN}$, the treatment of $\mathbf{3}$ with Magic Green led to the disappearance of the resonances of $\mathbf{3}$. However, paramagnetically shifted resonances of $3^{+}$are absent suggesting that the initially formed $3^{+}$undergoes further reactions with the coordinating solvent $\mathrm{CD}_{3} \mathrm{CN}$ (Figure S39, Supporting Information File 1). This finding underscores that the solvent has to be carefully chosen with respect to the mediated reaction and stability of the mediator.

From the observed ${ }^{1} \mathrm{H}$ NMR chemical shifts - either of the cyclopentadienyl or methyl resonances - the relative concentrations of the ferrocene and ferrocenium ion can be extracted, again allowing the estimation of the actual potential in solution by spectroscopic techniques.

\section{Conclusion}

Ferrocenyl esters 1-4 with one to four ester substituents are reversibly oxidized to the respective ferrocenium cations $\mathbf{1}^{+}-\mathbf{4}^{+}$, spanning a broad electrochemical potential range from $260 \mathrm{mV}$ for 1 to $900 \mathrm{mV}$ for $\mathbf{4} \mathrm{vs}$ the ferrocene/ferrocenium redox couple. The electrochemical potentials $E_{1 / 2}$ of 1-4 correlate linearly with the sum of Hammett substituent parameters $\sum \sigma_{\mathrm{p} / \mathrm{m}}$. However, the position of ester substituents has to be taken into account by employing $\sigma_{\mathrm{p}}$ for 1 - and 1 '-substituents and $\sigma_{\mathrm{m}}$ for

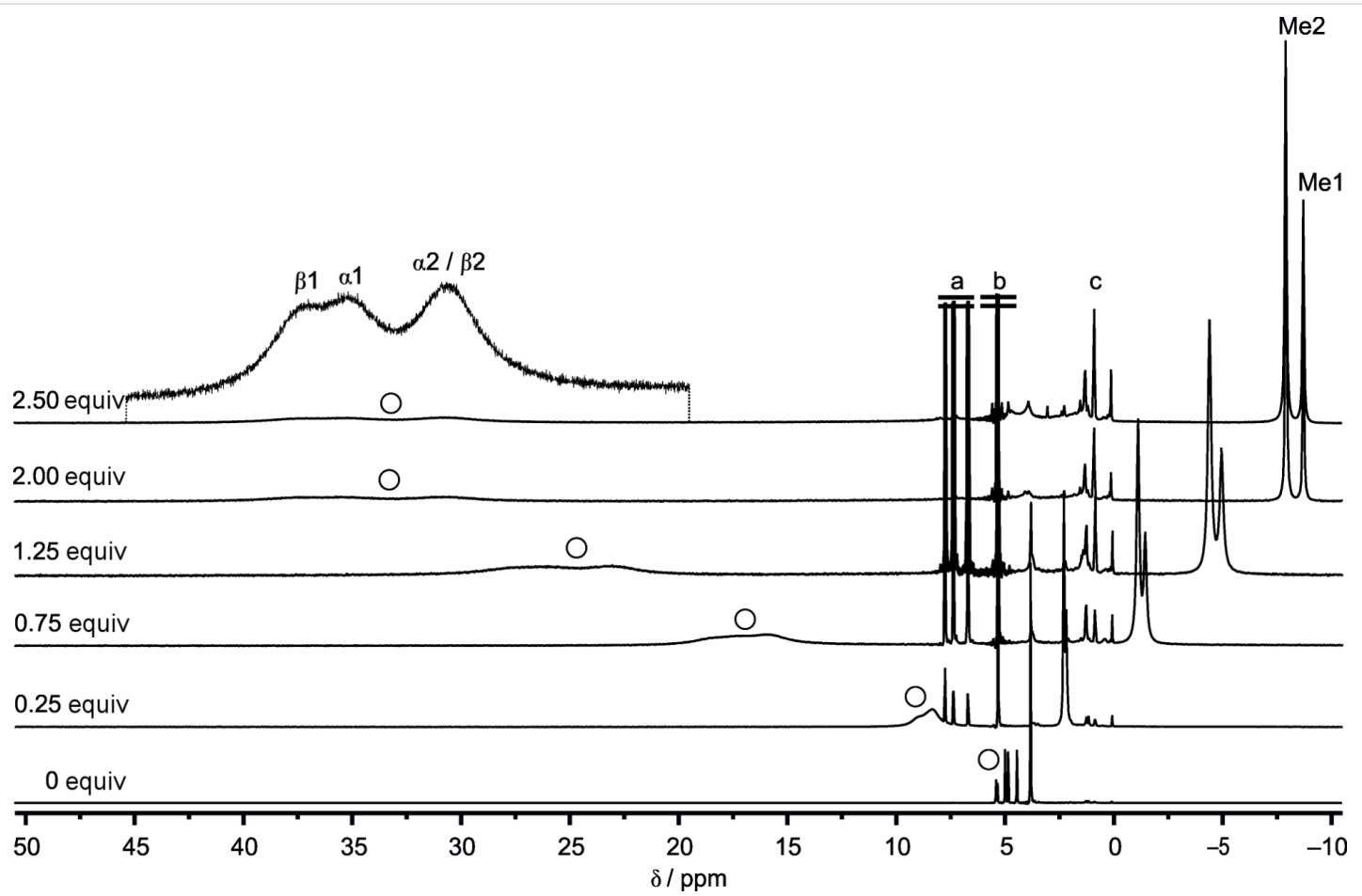

Figure 8: ${ }^{1} \mathrm{H}$ NMR oxidation titration of 3 in $\mathrm{CD}_{2} \mathrm{Cl}_{2}$ with $\left[\mathrm{N}\left(2,4-\mathrm{C}_{6} \mathrm{H}_{3} \mathrm{Br}_{2}\right)_{3}\right]^{+}$as oxidant. ${ }^{\mathrm{a}}\left[\mathrm{N}\left(2,4-\mathrm{C}_{6} \mathrm{H}_{3} \mathrm{Br}_{2}\right)_{3}\right] .{ }^{\mathrm{b}} \mathrm{CDHCl} 2 .{ }^{\mathrm{c}} \mathrm{Re}$ esidual solvents and grease. 
Table 2: ${ }^{1} \mathrm{H}$ NMR data $(\delta[\mathrm{ppm}])^{\mathrm{a}}$ of $1-4$ and $\mathbf{1}^{+}-\mathbf{4}^{+}$in $\mathrm{CD}_{2} \mathrm{Cl}_{2}$.

\begin{tabular}{|c|c|c|c|c|c|}
\hline & $\mathrm{H}^{\mathrm{Cp}}$ & $H^{\alpha 1} / H^{\beta 1}$ & $H^{\alpha 2} / H^{\beta 2}$ & $\mathrm{H}^{\mathrm{Me} 1}$ & $\mathrm{H}^{\mathrm{Me} 2}$ \\
\hline 1 & 4.20 & $4.40 / 4.77$ & & 3.76 & \\
\hline $1^{+}$ & 37.0 & $30.1 / 32.3$ & & -8.34 & \\
\hline 2 & & $4.42 / 4.79$ & & 3.78 & \\
\hline $2^{+}$ & & $34.0^{\mathrm{b}}$ & & -8.51 & \\
\hline 3 & & $4.43 / 4.84$ & $4.97 / 5.39$ & 3.79 & 3.80 \\
\hline $3^{+}$ & & $35.3 / 37.5$ & $30.7^{b}$ & -8.75 & -7.94 \\
\hline 4 & & & $4.98 / 5.42$ & & 3.87 \\
\hline $4^{+}$ & & & $33.6^{b}$ & & -8.26 \\
\hline
\end{tabular}

3- and 3'-substituents, respectively. Complexes 1-4 and $\mathbf{1}^{+}-\mathbf{4}^{+}$ are stable under conditions of electrolysis $\left(\mathrm{CH}_{2} \mathrm{Cl}_{2}\right.$, $\left.\left[n-\mathrm{Bu}_{4} \mathrm{~N}\right]\left[\mathrm{B}\left(\mathrm{C}_{6} \mathrm{~F}_{5}\right)_{4}\right]\right)$ as demonstrated by IR and UV-vis spectroelectrochemical experiments and ${ }^{1} \mathrm{H}$ NMR spectroscopy. The $\mathrm{C}=\mathrm{O}$ stretching vibrations of the ester substituents as characteristic probes in the IR spectra are consistently shifted to higher energies from $\mathbf{1}$ to $\mathbf{4}$ and from $\mathbf{1}^{+}$to $\mathbf{4}^{+}$. Upon oxidation of 1-4 to $\mathbf{1}^{+}-\mathbf{4}^{+}$in solution, the ferrocene bands in the UV-vis spectra of 1-4 at $\lambda_{\max }=444-457 \mathrm{~nm}$ and the LMCT bands of $\mathbf{1}^{+}-\mathbf{4}^{+}$at $\lambda_{\max }=633-672 \mathrm{~nm}$ bathochromically shift linearly with increasing number of ester groups. The ${ }^{1} \mathrm{H}$ NMR paramagnetic chemical shifts of $\mathbf{1}^{+}-\mathbf{4}^{+}$have been determined by redox titration experiments.

With all the data in hand, the molar fraction of the ester-substituted redox couples $1 / \mathbf{1}^{+}-\mathbf{4} / \mathbf{4}^{+}$can be accessed a) from the $\mathrm{C}=\mathrm{O}$ stretching vibrations of the ester groups, $b$ ) the ferrocenium $\mathrm{CT}$ bands or c) from the averaged ${ }^{1} \mathrm{H}$ NMR chemical shifts of the $\mathrm{Cp}$ or ester methyl protons. Ongoing investigations focus on the spectroscopic monitoring of 1-4 as redox mediators in selected electrosynthetic transformations.

\section{Experimental}

Dichloromethane, $\mathrm{CD}_{2} \mathrm{Cl}_{2}$ and $\mathrm{CD}_{3} \mathrm{CN}$ were distilled from calcium hydride. Electrochemical experiments were carried out on a BioLogic SP-50 voltammetric analyzer using a platinum working electrode, a platinum wire as counter electrode, and a $0.01 \mathrm{M} \mathrm{Ag} / \mathrm{AgNO}_{3} \mathrm{CH}_{3} \mathrm{CN}$ electrode as reference electrode. The measurements were carried out at a scan rate of $100 \mathrm{mV} \mathrm{s}^{-1}$ for cyclic voltammetry experiments and $100 \mathrm{mV} \mathrm{s}^{-1}$ for square wave voltammetry experiments using $0.1 \mathrm{M}\left[n-\mathrm{Bu}_{4} \mathrm{~N}\right]\left[\mathrm{B}\left(\mathrm{C}_{6} \mathrm{~F}_{5}\right)_{4}\right]$ as supporting electrolyte and $0.001 \mathrm{M}$ of the sample in dichloromethane. Potentials are given relative to the ferrocene/ferrocenium couple.
Spectroelectrochemical experiments were performed using a Specac omni-cell liquid transmission cell with $\mathrm{CaF}_{2}$ windows equipped with a Pt-gauze working electrode, a Pt-gauze counter electrode and an Ag wire as pseudo-reference electrode, meltsealed in a polyethylene spacer (approximate path length $0.5 \mathrm{~mm})$ in dichloromethane $(68,35,13,2 \mathrm{mM}$ solutions of 1-4 in $\mathrm{CH}_{2} \mathrm{Cl}_{2}$, containing $\left.0.1 \mathrm{M}\left[n-\mathrm{Bu}_{4} \mathrm{~N}\right]\left[\mathrm{B}\left(\mathrm{C}_{6} \mathrm{~F}_{5}\right)_{4}\right]\right)$ [88]. UV-vis/near-IR spectra were recorded on a Varian Cary 5000 spectrometer using $1.0 \mathrm{~cm}$ cells (Hellma, Suprasil). IR spectra were recorded on a Bruker Alpha FTIR spectrometer with ATR unit, containing a diamond crystal.

NMR spectra were recorded on a Bruker Avance DRX 400 spectrometer at $400.31 \mathrm{MHz}\left({ }^{1} \mathrm{H}\right)$ at $25{ }^{\circ} \mathrm{C}$. All resonances are reported in ppm versus the solvent signal as internal standard: $\mathrm{CD}_{2} \mathrm{Cl}_{2}\left({ }^{1} \mathrm{H}, \delta=5.32 \mathrm{ppm}\right), \mathrm{CD}_{3} \mathrm{CN}\left({ }^{1} \mathrm{H}, \delta=1.94 \mathrm{ppm}\right)$ [89].

DFT calculations were carried out using the ORCA program package (version 4.0.1) [90]. All calculations were performed using the B3LYP functional [91-93] and employ the RIJCOSX approximation $[94,95]$. Relativistic effects were calculated at the zeroth order regular approximation (ZORA) level [96]. The ZORA keyword automatically invokes relativistically adjusted basis sets. To account for solvent effects, a conductor-like screening model (CPCM) modeling dichloromethane was used in all calculations [97]. Geometry optimizations and TD-DFT calculations (50 vertical transitions) were performed using Ahlrichs' split-valence triple- $\xi$ basis set def2-TZVP which comprises polarization functions for all non-hydrogen atoms [98,99]. The presence of energy minima was checked by numerical frequency calculations. Explicit counterions and/or solvent molecules were not taken into account.

\section{Supporting Information}

The Supporting Information file contains square wave voltammograms, IR and UV-vis spectra of the spectroelectrochemical experiments, (TD)-DFT calculated IR and UV-vis spectra, a table with IR data, ${ }^{1} \mathrm{H}$ NMR spectra of the oxidation titration experiments and Cartesian coordinates of DFT calculated structures of 1-4.

\section{Supporting Information File 1}

Mediators measured and calculated spectra, IR data and Cartesian coordinates.

[https://www.beilstein-journals.org/bjoc/content/ supplementary/1860-5397-14-86-S1.pdf] 


\section{Acknowledgements}

Financial support from the Rhein-Main-Universities initiative "Novel Concepts in Selective Electro-conversions for Addedvalue Chemicals" is gratefully acknowledged.

\section{ORCID ${ }^{\circledR}$ iDs}

Jan Klett - https://orcid.org/0000-0002-0055-5335

Katja Heinze - https://orcid.org/0000-0003-1483-4156

\section{References}

1. Togni, A.; Hayashi, T. Ferrocenes; Wiley-VCH Verlag GmbH: Weinheim, Germany, 1994.

2. Štěpnička, P., Ed. Ferrocenes. Ligands, materials and biomolecules; J. Wiley: Chichester, England, 2008.

3. Astruc, D. Eur. J. Inorg. Chem. 2017, 6-29. doi:10.1002/ejic.201600983

4. Pavlishchuk, V. V.; Addison, A. W. Inorg. Chim. Acta 2000, 298, 97-102. doi:10.1016/S0020-1693(99)00407-7

5. Yang, E. S.; Chan, M.-S.; Wahl, A. C. J. Phys. Chem. 1980, 84, 3094-3099. doi:10.1021/j100460a025

6. Nielson, R. M.; McManis, G. E.; Safford, L. K.; Weaver, M. J. J. Phys. Chem. 1989, 93, 2152-2157. doi:10.1021/j100342a086

7. Gagne, R. R.; Koval, C. A.; Lisensky, G. C. Inorg. Chem. 1980, 19, 2854-2855. doi:10.1021/ic50211a080

8. Gritzner, G.; Kuta, J. Pure Appl. Chem. 1984, 56, 461-466. doi:10.1351/pac198456040461

9. Noviandri, I.; Brown, K. N.; Fleming, D. S.; Gulyas, P. T.; Lay, P. A.; Masters, A. F.; Phillips, L. J. Phys. Chem. B 1999, 103, 6713-6722. doi:10.1021/jp991381+

10. Connelly, N. G.; Geiger, W. E. Chem. Rev. 1996, 96, 877-910. doi:10.1021/cr940053x

11. Steckhan, E. Angew. Chem., Int. Ed. Engl. 1986, 25, 683-701. doi:10.1002/anie.198606831

12. Francke, R.; Little, R. D. Chem. Soc. Rev. 2014, 43, $2492-2521$. doi:10.1039/c3cs60464k

13. Wiebe, A.; Gieshoff, T.; Möhle, S.; Rodrigo, E.; Zirbes, M.; Waldvogel, S. R. Angew. Chem., Int. Ed. 2018, 57, 2-28. doi:10.1002/anie.201711060

14. Jiang, Y.; Xu, K.; Zeng, C. Chem. Rev. 2018, in press. doi:10.1021/acs.chemrev.7b00271

15. Ding, Y.; Yu, G. Angew. Chem., Int. Ed. 2017, 56, 8614-8616. doi:10.1002/anie.201701254

16. Raoof, J. B.; Ojani, R.; Karimi-Maleh, H.; Hajmohamadi, M. R.; Biparva, P. Anal. Methods 2011, 3, 2637-2643. doi:10.1039/c1ay05031a

17. Jahn, U. J. Org. Chem. 1998, 63, 7130-7131. doi:10.1021/jo981180m

18. Langer, T.; Illich, M.; Helmchen, G. Synlett 1996, 1996, 1137-1139. doi:10.1055/s-1996-5668

19. Jahn, U.; Müller, M.; Aussieker, S. J. Am. Chem. Soc. 2000, 122, 5212-5213. doi:10.1021/ja000565v

20. Jahn, U.; Hartmann, P.; Dix, I.; Jones, P. G. Eur. J. Org. Chem. 2001, 3333-3355 doi:10.1002/1099-0690(200109)2001:17<3333::aid-ejoc3333>3.0.co;2a

21. Pigge, F. C.; Coniglio, J. J.; Rath, N. P. J. Org. Chem. 2004, 69, 1161-1168. doi:10.1021/jo035058I

22. Sibi, M. P.; Hasegawa, M. J. Am. Chem. Soc. 2007, 129, 4124-4125. doi:10.1021/ja069245n
23. Goddard, J.-P.; Gomez, C.; Brebion, F.; Beauvière, S.; Fensterbank, L.; Malacria, M. Chem. Commun. 2007, 2929-2931. doi:10.1039/b705284g

24. Richter, J. M.; Whitefield, B. W.; Maimone, T. J.; Lin, D. W.; Castroviejo, M. P.; Baran, P. S. J. Am. Chem. Soc. 2007, 129, 12857-12869. doi:10.1021/ja074392m

25. Krygowski, E. S.; Murphy-Benenato, K.; Shair, M. D. Angew. Chem., Int. Ed. 2008, 47, 1680-1684. doi:10.1002/anie. 200704830

26. Jahn, U.; Dinca, E. Chem. - Eur. J. 2009, 15, 58-62. doi:10.1002/chem.200802139

27. Khobragade, D. A.; Mahamulkar, S. G.; Pospíšil, L.; Císařová, I.; Rulíšek, L.; Jahn, U. Chem. - Eur. J. 2012, 18, 12267-12277. doi:10.1002/chem.201201499

28. Holan, M.; Pohl, R.; Císařová, I.; Klepetářová, B.; Jones, P. G.; Jahn, U. Chem. - Eur. J. 2015, 21, 9877-9888. doi:10.1002/chem.201500424

29. Chernyak, N.; Buchwald, S. L. J. Am. Chem. Soc. 2012, 134, 12466-12469. doi:10.1021/ja305660a

30. Marciasini, L. D.; Richy, N.; Vaultier, M.; Pucheault, M. Adv. Synth. Catal. 2013, 355, 1083-1088. doi:10.1002/adsc.201200942

31. Foo, K.; Sella, E.; Thomé, I.; Eastgate, M. D.; Baran, P. S. J. Am. Chem. Soc. 2014, 136, 5279-5282. doi:10.1021/ja501879c

32. Hernández-Muñoz, L. S.; Fragoso-Soriano, R. J.; Vázquez-López, C.; Klimova, E.; Ortiz-Frade, L. A.; Astudillo, P. D.; González, F. J. J. Electroanal. Chem. 2010, 650, 62-67. doi:10.1016/j.jelechem.2010.09.006

33. Hernández-Muñoz, L. S.; Galano, A.; Astudillo-Sánchez, P. D.; Abu-Omar, M. M.; González, F. J. Electrochim. Acta 2014, 136, 542-549. doi:10.1016/j.electacta.2014.04.189

34. Hou, Z.-W.; Mao, Z.-Y.; Zhao, H.-B.; Melcamu, Y. Y.; Lu, X.; Song, J.; Xu, H.-C. Angew. Chem., Int. Ed. 2016, 55, 9168-9172. doi:10.1002/anie.201602616

35. Wu, Z.-J.; Xu, H.-C. Angew. Chem., Int. Ed. 2017, 56, 4734-4738. doi:10.1002/anie.201701329

36. Zhu, L.; Xiong, P.; Mao, Z.-Y.; Wang, Y.-H.; Yan, X.; Lu, X.; Xu, H.-C. Angew. Chem., Int. Ed. 2016, 55, 2226-2229. doi:10.1002/anie.201510418

37. Brown, K. N.; Gulyas, P. T.; Lay, P. A.; McAlpine, N. S.; Masters, A. F.; Phillips, L. J. Chem. Soc., Dalton Trans. 1993, 835-840. doi:10.1039/DT9930000835

38. Hildebrandt, A.; Khalyfeh, K. A.; Schaarschmidt, D.; Korb, M. J. Organomet. Chem. 2016, 804, 87-94. doi:10.1016/j.jorganchem.2015.12.027

39. Lu, S.; Strelets, V. V.; Ryan, M. F.; Pietro, W. J.; Lever, A. B. P. Inorg. Chem. 1996, 35, 1013-1023. doi:10.1021/ic950620e

40. Thornberry, M. P.; Slebodnick, C.; Deck, P. A.; Fronczek, F. R. Organometallics 2000, 19, 5352-5369. doi:10.1021/om000798v

41. Rhode, C.; Lemke, J.; Lieb, M.; Metzler-Nolte, N. Synthesis 2009, 2009, 2015-2018. doi:10.1055/s-0029-1216812

42. Nieto, D.; Bruña, S.; Montero-Campillo, M. M.; Perles, J.; González-Vadillo, A. M.; Méndez, J.; Mo, O.; Cuadrado, I. Chem. Commun. 2013, 49, 9785-9787. doi:10.1039/c3cc44619k

43. Sünkel, K.; Weigand, S.; Hoffmann, A.; Blomeyer, S.; Reuter, C. G.; Vishnevskiy, Y. V.; Mitzel, N. W. J. Am. Chem. Soc. 2015, 137, 126-129. doi:10.1021/ja511588p

44. Inkpen, M. S.; Du, S.; Hildebrand, M.; White, A. J. P.; Harrison, N. M.; Albrecht, T.; Long, N. J. Organometallics 2015, 34, 5461-5469. doi:10.1021/acs.organomet.5b00811 
45. Benkeser, R. A.; Goggin, D.; Schroll, G. J. Am. Chem. Soc. 1954, 76, 4025-4026. doi:10.1021/ja01644a047

46. Witte, P.; Lal, T. K.; Waymouth, R. M. Organometallics 1999, 18, 4147-4155. doi:10.1021/om990083w

47. Woodward, R. B.; Rosenblum, M.; Whiting, M. C. J. Am. Chem. Soc. 1952, 74, 3458-3459. doi:10.1021/ja01133a543

48. Sonoda, A.; Moritani, I. J. Organomet. Chem. 1971, 26, 133-140. doi:10.1016/S0022-328X(00)80600-2

49. Petrov, A. R.; Jess, K.; Freytag, M.; Jones, P. G.; Tamm, M. Organometallics 2013, 32, 5946-5954. doi:10.1021/om4004972

50. Werner, G.; Butenschön, H. Eur. J. Inorg. Chem. 2017, 378-387. doi:10.1002/ejic.201600766

51. Hisatome, M.; Tachikawa, O.; Sashō, M.; Yamakawa, K. J. Organomet. Chem. 1981, 217, C17-C20. doi:10.1016/S0022-328X(00)86033-7

52. Kasahara, A.; Izumi, T.; Yoshida, Y.; Shimizu, I. Bull. Chem. Soc. Jpn. 1982, 55, 1901-1906. doi:10.1246/bcsj.55.1901

53. Deschenaux, R.; Kosztics, I.; Nicolet, B. J. Mater. Chem. 1995, 5, 2291-2295. doi:10.1039/jm9950502291

54. Klett, J. Chem. - Eur. J. 2018, in press. doi:10.1002/chem.201800608.

55. Bruce, M. I.; Skelton, B. W.; Wallis, R. C.; Walton, J. K.; White, A. H.; Williams, M. L. J. Chem. Soc., Chem. Commun. 1981, 428-430. doi:10.1039/C39810000428

56. Bruce, M. I.; Walton, J. K.; Williams, M. L.; Patrick, J. M.; Skelton, B. W.; White, A. H. J. Chem. Soc., Dalton Trans. 1983, 815-821. doi:10.1039/dt9830000815

57. Rausch, M. D.; Ciappenelli, D. J. J. Organomet. Chem. 1967, 10, 127-136. doi:10.1016/S0022-328X(00)81725-8

58. Sanders, R.; Mueller-Westerhoff, U. T. J. Organomet. Chem. 1996, 512, 219-224. doi:10.1016/0022-328X(95)05914-B

59. Bishop, J. J.; Davison, A.; Katcher, M. L.; Lichtenberg, D. W. Merrill, R. E.; Smart, J. C. J. Organomet. Chem. 1971, 27, 241-249. doi:10.1016/S0022-328X(00)80571-9

60. Butler, I. R.; Cullen, W. R.; Ni, J.; Rettig, S. J. Organometallics 1985, 4, 2196-2201. doi:10.1021/om00131a023

61. Reeves, P. C. Org. Synth. 1977, 56, 28. doi:10.15227/orgsyn.056.0028

62. Kaim, W.; Klein, A. Spectroelectrochemistry; Royal Society of Chemistry: Cambridge, 2008.

63. Kaim, W.; Fiedler, J. Chem. Soc. Rev. 2009, 38, 3373-3382. doi:10.1039/b504286k

64. Siebler, D.; Linseis, M.; Gasi, T.; Carrella, L. M.; Winter, R. F.; Förster, C.; Heinze, K. Chem. - Eur. J. 2011, 17, 4540-4551. doi:10.1002/chem.201002101

65. Neidlinger, A.; Ksenofontov, V.; Heinze, K. Organometallics 2013, 32 , 5955-5965. doi:10.1021/om400498h

66. Kienz, T.; Förster, C.; Heinze, K. Organometallics 2014, 33, 4803-4812. doi:10.1021/om500052k

67. Hüttinger, K.; Förster, C.; Heinze, K. Chem. Commun. 2014, 50, 4285-4288. doi:10.1039/C3CC46919K

68. Preiß, S.; Melomedov, J.; Wünsche von Leupoldt, A.; Heinze, K. Chem. Sci. 2016, 7, 596-610. doi:10.1039/C5SC03429A

69. Bertini, I.; Luchinat, C.; Parigi, G. Solution NMR of paramagnetic molecules. Applications to metallobiomolecules and models. Current methods in inorganic chemistry 2, 1st ed.; Elsevier, 2001.

70. Siebler, D.; Förster, C.; Gasi, T.; Heinze, K. Organometallics 2011, 30 , 313-327. doi:10.1021/om1010808

71. Siebler, D.; Förster, C.; Heinze, K. Dalton Trans. 2011, 40, 3558-3575. doi:10.1039/c0dt01528h

72. Förster, C.; Veit, P.; Ksenofontov, V.; Heinze, K. Chem. Commun. 2015, 51, 1514-1516. doi:10.1039/C4CC08868A
73. Preiß, S.; Förster, C.; Otto, S.; Bauer, M.; Müller, P.; Hinderberger, D.; Haeri, H. H.; Carella, L.; Heinze, K. Nat. Chem. 2017, 9, 1249-1255. doi:10.1038/nchem.2836

74. Gubin, S. P. Pure Appl. Chem. 1970, 23, 463-488. doi:10.1351/pac197023040463

75. Hansch, C.; Leo, A.; Taft, R. W. Chem. Rev. 1991, 91, 165-195. doi:10.1021/cr00002a004

76. Beck,, W.; Woisetschläger, O. E.; Mayer, P. Z. Kristallogr. - New Cryst. Struct. 2001, 216, 403-404. doi:10.1524/ncrs.2001.216.14.425

77. Cetina, M.; Jukić, M.; Rapic, V.; Golobic, A. Acta Crystallogr., Sect. C: Struct. Chem. 2003, 59, m212-m214. doi:10.1107/S0108270103008503

78. For the redox couple 4/4+, an additional shoulder at $\tilde{\mathrm{v}}_{\mathrm{CO}}=1710 \mathrm{~cm}^{-1}$ is observed during oxidation (Figure S13, Supporting Information File 1). The intensity of this shoulder also increases upon re-reduction (Figure S14, Supporting Information File 1) and hence is tentatively assigned to the $\mathrm{C}=\mathrm{O}$ stretching vibration of solid $\mathbf{4}$ (Figure $3 \mathrm{a}$ ), as a consequence of precipitation due to the lower solubility of $\mathbf{4}$ in $\mathrm{CH}_{2} \mathrm{Cl}_{2}$.

79. Gray, H. B.; Sohn, Y. S.; Hendrickson, N. J. Am. Chem. Soc. 1971, 93, 3603-3612. doi:10.1021/ja00744a011

80. Yamaguchi, Y.; Ding, W.; Sanderson, C. T.; Borden, M. L.; Morgan, M. J.; Kutal, C. Coord. Chem. Rev. 2007, 251, 515-524. doi:10.1016/j.ccr.2006.02.028

81. Sohn, Y. S.; Hendrickson, D. N.; Gray, H. B. J. Am. Chem. Soc. 1970, 92, 3233-3234. doi:10.1021/ja00713a079

82. Hendrickson, D. N.; Sohn, Y. S.; Duggan, D. M.; Gray, H. B. J. Chem. Phys. 1973, 58, 4666-4675. doi:10.1063/1.1679029

83. Fulara, J.; Filipkowski, K.; Maier, J. P. J. Phys. Chem. C 2017, 121, 10694-10697. doi:10.1021/acs.jpcc.6b10391

84. Li, Y. L.; Han, L.; Mei, Y.; Zhang, J. Z. H. Chem. Phys. Lett. 2009, 482, 217-222. doi:10.1016/j.cplett.2009.10.026

85. Yáñez-S, M.; Moya, S. A.; Zúñiga, C.; Cárdenas-Jirón, G. Comput. Theor. Chem. 2017, 1118, 65-74. doi:10.1016/j.comptc.2017.08.032

86. Salzner, U. J. Chem. Theory Comput. 2013, 9, 4064-4073. doi:10.1021/ct400322v

87. Bluemel, J.; Hebendanz, N.; Hudeczek, P.; Koehler, F. H.; Strauss, W. J. Am. Chem. Soc. 1992, 114, 4223-4230. doi:10.1021/ja00037a028

88. Krejčik, M.; Daněk, M.; Hartl, F. J. Electroanal. Chem. Interfacial Electrochem. 1991, 317, 179-187. doi:10.1016/0022-0728(91)85012-E

89. Fulmer, G. R.; Miller, A. J. M.; Sherden, N. H.; Gottlieb, H. E.; Nudelman, A.; Stoltz, B. M.; Bercaw, J. E.; Goldberg, K. I. Organometallics 2010, 29, 2176-2179. doi:10.1021/om100106e

90. Neese, F. Wiley Interdiscip. Rev.: Comput. Mol. Sci. 2012, 2, 73-78. doi: $10.1002 /$ wcms.81

91. Becke, A. D. J. Chem. Phys. 1993, 98, 5648-5652. doi:10.1063/1.464913

92. Lee, C.; Yang, W.; Parr, R. G. Phys. Rev. B 1988, 37, 785-789. doi:10.1103/PhysRevB.37.785

93. Miehlich, B.; Savin, A.; Stoll, H.; Preuss, H. Chem. Phys. Lett. 1989, 157, 200-206. doi:10.1016/0009-2614(89)87234-3

94. Neese, F.; Wennmohs, F.; Hansen, A.; Becker, U. Chem. Phys. 2009, 356, 98-109. doi:10.1016/j.chemphys.2008.10.036

95. Izsák, R.; Neese, F. J. Chem. Phys. 2011, 135, 144105. doi:10.1063/1.3646921

96. Pantazis, D. A.; Chen, X.-Y.; Landis, C. R.; Neese, F. J. Chem. Theory Comput. 2008, 4, 908-919. doi:10.1021/ct800047t 
97. Sinnecker, S.; Rajendran, A.; Klamt, A.; Diedenhofen, M.; Neese, F. J. Phys. Chem. A 2006, 110, 2235-2245. doi:10.1021/jp056016z

98. Weigend, F.; Ahlrichs, R. Phys. Chem. Chem. Phys. 2005, 7, 3297-3305. doi:10.1039/b508541a

99. Weigend, F. Phys. Chem. Chem. Phys. 2006, 8, 1057-1065. doi:10.1039/b515623h

\section{License and Terms}

This is an Open Access article under the terms of the Creative Commons Attribution License

(http://creativecommons.org/licenses/by/4.0), which permits unrestricted use, distribution, and reproduction in any medium, provided the original work is properly cited.

The license is subject to the Beilstein Journal of Organic Chemistry terms and conditions:

(https://www.beilstein-journals.org/bjoc)

The definitive version of this article is the electronic one which can be found at: doi:10.3762/bjoc. 14.86 